How to cite this article:

Jeyaraj, J. J. (2020). Academic writing needs of postgraduate research students in Malaysia. Malaysian Journal of Learning and Instruction, 17(2), 1-23. https:// doi.org/10.32890/mjli2020.17.2.1

\title{
ACADEMIC WRITING NEEDS OF POSTGRADUATE RESEARCH STUDENTS IN MALAYSIA
}

\author{
Joanna Joseph Jeyaraj \\ Faculty of Social Science and Humanities, \\ Tunku Abdul Rahman University College \\ joannajj@tarc.edu.my
}

Received: 20/2/2019 Revised: 14/4/2020 Accepted: 4/5/2020 Published:31/7/2020

\begin{abstract}
Purpose - In this study, the writing needs of postgraduate research students are explored, so that support structures that enable successful completion rates and student satisfaction can be identified. Postgraduate education is expanding in Malaysian public and private higher education institutions; yet research tends to focus on public institutions, because private institutions have traditionally been oriented towards teaching instead of research. Therefore, this study explores the needs of students in a branch campus of a private overseas university in Malaysia.
\end{abstract}

Methodology - Semi-structured exploratory interviews were carried out with six postgraduate students, so that a deeper understanding of their research writing needs could be obtained. Interviews were then analysed using a general inductive approach.

Findings - It was found that students required support in three main areas: writing, supervision and ICT. Students sought English language support and more workshops and programmes which specifically dealt with thesis writing. They also believed that peer support groups would be beneficial. Secondly, more guidance was needed from supervisors to enable greater clarity on writing and 
institutional processes and procedures. Finally, students wanted greater access to ICT writing tools to facilitate writing and language learning.

Significance - The findings of this study are beneficial to institutions seeking to provide greater support for postgraduate students to ensure timely completion rates and greater student satisfaction. Based on the findings of this study, it is recommended that postgraduate support incorporate 3Ps, i.e., be pedagogically driven; peer oriented; and programmatically implemented.

Keywords: Postgraduate research writing, academic writing, thesis, postgraduate support.

\section{INTRODUCTION}

The process of writing a thesis in the English language is regarded as a challenge for many postgraduate students, and those from non-English speaking backgrounds (NESB) have an extra burden because they need to contend with the linguistic demands of writing in this genre (Li \& Vandermensbrugghe, 2011; Phakiti \& Li, 2011). In this study, focus is placed on NESB students to identify areas of support they find important in facilitating the research writing process. In Malaysia, which is the context of this study, the focus on postgraduate education is increasing in both public and private institutions of higher learning. One reason for this is the 'push' to increase the number of $\mathrm{PhD}$ holders to 60,000 by 2023 (Ministry of Education Malaysia, 2015). As a result, there has been a rather remarkable expansion in the number of $\mathrm{PhD}$ students enrolled in both public and private universities. Between 2007 to 2014 alone, the percentage of $\mathrm{PhD}$ students increased by $236 \%$ (Ministry of Education Malaysia, 2015). One of Malaysia's aspirations was to widen access and participation in higher education and over a ten year period, it has managed to obtain a tenfold increase in Masters and $\mathrm{PhD}$ enrolment, ranking it third among other ASEAN countries like Singapore and Thailand (Ministry of Education Malaysia, 2015).

Although postgraduate numbers in Malaysia have risen dramatically, the number of $\mathrm{PhD}$ graduates has not been significant due to high 
attrition rates (Sidhu, Kaur, Fook, \& Yunus, 2014). This situation has been described as 'worrisome' (Zainal Abiddin \& Ismail, 2011) and 'quite alarming' (Zakariah, Hashim, \& Musa, 2018). For example, Mohd Isa and Ahmad (2018) note that between 2006 and 2016, the Faculty of Administrative Science and Policy Studies in Universiti Teknologi MARA (UiTM) experienced rather low completion rates of $10.9 \%$ and $10.7 \%$ among Masters by research and $\mathrm{PhD}$ students respectively. In a study they conducted among postgraduate students in this faculty, academic writing was identified as a major challenge. To address this issue, a Graduate Researches in Print (GRiP) programme, which aimed to assist students in research writing was conducted so that by identifying the writing needs of students, steps to mitigate the problem of attrition could be undertaken. Additionally, future students could be supported in more strategic ways to enhance academic success.

The interest in conducting this study developed because it was recognised that timely completion was an important issue that universities were grappling with. The aim of this study was to identify the writing needs of postgraduate students in an overseas university which has a campus in Malaysia. Expanding transnational education has led to the emergence of international branch campuses, where the students and the awarding institution are situated in different countries (Wilkins \& Huisman, 2012). In Malaysia alone, more than 10 overseas universities have set up branch campuses. Yet, studies which explore the needs of students in this context remains limited. Postgraduate education is important for private institutions because they need to remain competitive and generate income through student fees as well as industry and research engagement. Therefore, the following research question guided the inquiry: What are the writing needs of postgraduate research students in this branch campus in Malaysia?

By identifying students' writing needs and areas of support, steps to mitigate untimely completion rates among postgraduate students can be addressed and areas which could lead to greater student satisfaction can be determined. In the following sections, a brief literature review and methods are presented. Three main themes that emerged are then discussed in relation to the literature surrounding postgraduate education. Finally, a summary is presented, with a 3P approach to postgraduate support proposed. 


\section{LITERATURE REVIEW}

\section{Postgraduate Research Writing in Malaysia}

Although Malaysia is developing in terms of postgraduate education, literature in research writing is relatively sparse (Sidhu, Kaur, Fook, \& Yunus, 2013). Some recent examples of studies in this area are Sidhu, Kaur, Lim, and Fook (2016) and Lim, Sidhu, Fook, Fong, and Jamian (2016) who explored the reading and writing skills of postgraduate students based on the perceptions of supervisors and students. There are also a handful of studies which have specifically focused on the writing experiences and challenges of international students in public Malaysian universities. Some of these studies have reported the experiences of Arab students in particular, and have revealed that students experienced writing apprehension (Huwari \& Abd.Aziz, 2011) as well as difficulties relating to vocabulary, sentence structure and clarity in writing (Abdulkareen, 2013). Furthermore, they faced citation related challenges when writing for academic purposes (Jomaa \& Bidin, 2017). While all these studies examined postgraduate writing, the focus has been solely on students in public institutions. The experiences of students from privately run institutions such as overseas universities with branch campuses in the country are limited.

Aside from language-related challenges, numerous other contributing factors have been found to hinder the entire postgraduate writing process.Zainal Abiddin and Ismail (2011) noted that inaccessibility to resources and guidance support by the institution negatively impacted student performance and quality of work. Additionally, Khozaei, Naidu, Khozaei, and Salleh (2015) highlighted other obstacles which included student characteristics, financial constraints, family commitment, psychological barriers and quality of supervision. In the case of international postgraduate students, there have been instances where education obtained from the home countries at the bachelor's degree level did not adequately prepare students for the rigour and demands of postgraduate study in Malaysia, as teaching and learning styles differed considerably (Ibrahim \& Nambiar, 2011). Drawing on the experiences of postgraduate students from two public universities, Sidhu et al. (2013) found that limited knowledge in research methodology, academic writing, limited access to resources, and quality and timeliness of feedback affected 
the research writing process. Therefore, both personal and external factors such as institutional and supervisory support are important in impacting timely completion as well as study progress and success.

\section{Supporting Postgraduate Research Writing Needs}

\section{a) Supervisory support}

Research supervision has been recognised as vital to successful postgraduate completion. Many institutions have a variety of approaches to supervision, the most common being an apprenticeship model, where an academic staff member who has expertise in a particular area of study is appointed as the candidate's supervisor. Other models have emerged over the years, such as collaborative cohort models (Burnett, 1999), and supervisor mentoring (de Lange, Pillay, \& Chikoko, 2011; Paglis, Green, \& Bauer, 2006). One particular doctoral cohort model of supervision which was underpinned by the idea of collaborative and community research brought together a group of academics from various fields to support a cohort of doctoral students over a period of three years, in three phases. These three phases included the stages of 1) refining and finalizing the research proposal; 2) data generation; and 3) data analysis and 'writing it up' (de Lange et al., 2011).

Highly successful supervisors recognise that supervision is not a one-size-fits-all model, and therefore adopt different practices depending on their students' needs and stage of candidature (Nulty, Kiley, \& Meyers, 2009). Sidhu et al. (2013) explain that effective supervisory practices include good relationship management with students; with supervisors being friendly, open, approachable and supportive. Because supervisors impact students' publication activity, research intensive universities strive towards developing supervisory excellence (Nulty et al., 2009). However, the notion of excellence in supervision in the Australian context has been described as an elusive concept, with national authoritative statements focusing much on policy and process, with little mention on the nature of supervisory practice (McCulloch, Kumar, van Schalkwyk, \& Wisker, 2016). Even though effective supervision can positively affect student satisfaction, completion rates and research output, many supervisors have not received adequate training on how to provide 'good' supervision. They rely on the way they were 
supervised and their ideas of what 'good' supervision is; at the same time, they perceive that writing is 'common sense' and a universal skill (Starke-Meyerring, 2011). Such problematic assumptions can potentially compromise the quality of effective supervision.

\section{b) Peer support}

The postgraduate journey has often been described as isolating and lonely (Fergie, Beeke, Mckenna, \& Creme, 2011; Jeyaraj, 2018). Numerous institutions have addressed this problem by providing a range of peer-related support services because this form of support has resulted in timely completion among students (Buissink-Smith, Hart, \& van der Meer, 2013). For instance, to address the social aspect of writing, peer writing groups have been set up so that students can gather to give and receive feedback on their writing. While writing groups can be formed among students from similar disciplines, they can also be multidisciplinary. Fergie et al. (2011) found that writing is best situated within a disciplinary and programme context because systematic attention can be given to writing. Similarly, Wilmot (2018) who examined both disciplinary and multidisciplinary writing groups found that one challenge students from multidisciplinary groups faced was disciplinary knowledge building through writing, because it was not always possible to obtain disciplinary advice from peers. Writing retreats, another type of peer support, also enhances the writing process because members are able to develop a specific skill within a supportive environment where time and space are purposefully allocated for writing (Davis, Wright, \& Holley, 2016). Writing retreats can manifest in different ways; one being a 'structured' form where emphasis is placed on goal-setting, discussion and peer review on writing progress (Murray \& Newton, 2009).

In Australia and New Zealand, Peer Assisted Student Support (PASS) programmes exist where typically high achieving senior students facilitate weekly one-hour sessions. International postgraduate students have found this form of learning support beneficial because they are able to understand content better, get improved grades for their coursework, and at the same time improve their English language proficiency (Zaccagnini \& Verenikina, 2013). BuissinkSmith, Hart, and van der Meer (2013) describe an initiative which involved the manufacturing of peer learning groups. They report 
that group members felt a sense of belonging as they managed to connect with others within the university and celebrate important research milestones together. Additionally, there was also structure to the groups and a sense of membership. Lee (2017) recounted how students in a Postgraduate Students' Association in a New Zealand university were able to have an avenue to voice concerns, understand how to communicate with supervisors and obtain guidance with difficult situations.

\section{c) Academic skills and researcher development support}

To respond to the needs of students, an array of interventionist strategies and support services are commonly provided for students, typically by centralised departments that address academic and writing skills development (Carter, 2011). Most often, skillsbased approaches have been implemented in the form of add-on writing skills courses, one-off thesis writing workshops and 'howto' programmes (Badenhorst, Moloney, \& Rosales, 2015). Some examples include English for Academic Purposes (EAP) support programmes (Larcombe, McCosker, \& O'Loughlin, 2007; Son \& Park, 2014; Storch \& Tapper, 2009) researcher development workshops (Franken, 2012) academic presentation skills seminars (Ohnishi \& Ford, 2015), and individual writing consultations with learning advisors (Woodward-Kron, 2007). While many institutions have learning centres specially designed to provide these forms of generic support, discipline-specific support is also provided by numerous institutions.

Additionally, researcher development initiatives have been carried out through academic preparation programmes (Jones, Farrell, \& Goldsmith, 2009), research methods workshops (Wisker, Robinson, Trafford, Lilly, \& Warnes, 2004), and academic career preparation (Curtin, Malley, \& Stewart, 2016) and mentoring programmes (Atkins et al., 2016; Paglis et al., 2006). Mentorship programmes provide students with important feedback on their performance, and give encouragement and pragmatic information on how to acquire the skills necessary to succeed in a given field (Curtin et al., 2016). The long-term effects of mentoring have been studied, and it has been found that psychosocial mentoring positively influenced subsequent research productivity and self-efficacy. (Paglis et al., 2006). Atkins et al. (2016) describe a less formal mentoring initiative 
in health research, in the form of an online journal club or 'Research Clinic', where emerging young leaders from low and middleincome groups and international health leaders and researchers were brought together. Mentorship for academic career preparation is also provided in some institutions because it relates to doctoral student satisfaction and productivity, as well as long-term success as faculty members (Curtin et al., 2016).

Postgraduate support is a dynamic and complex endeavour which involves effective supervision, peer support and academic and researcher skill development. In the results and discussion section, literature into postgraduate education and support shall be used as a basis to analyse and gain deeper insights into the writing needs of the participants in this study.

\section{METHODOLOGY}

This study focused on the writing needs of NESB students in an international branch campus of an overseas university in Malaysia. This institution is a relatively 'young' institution compared with other public universities in the country. At the time of the study, approximately 100 research Masters and $\mathrm{PhD}$ students were enrolled. Informal conversations with staff and students revealed that postgraduate research writing support received limited attention, and no long-term formalised approach was available to facilitate the research writing process.

My beliefs have guided the research design and methods in this study, and they stem from:

- a relativist ontology which embraces the idea of multiple realities (Cresswell, 2007; Denzin \& Lincoln, 2003);

- an antifoundational epistemology which refuses to adopt any permanent or foundational standard by which truth can be universally known (Lincoln \& Guba, 2003); and

- the view of knowledge as a construction of the participant's experience and action (Czarniawska, 2004).

Before the study commenced, ethical clearance was gained from the Human Research Ethics Committee of both the branch campus in Malaysia and the main campus overseas. Participant recruitment 
was done through an e-mail call for participation and student referrals. Only participants who had at least six months of fulltime study were sought, so that they would have sufficient research writing experiences to draw upon. Although eight students initially expressed interest in the project, only six confirmed participation. All were from non-English speaking backgrounds and were pursuing postgraduate research degrees in the Sciences. Four were Masters students, while two were Doctoral students.

Table 1 provides information about the participants. Because this university has a relatively small postgraduate student population, their specific areas of study will not be disclosed to protect their anonymity.

Table 1

Participants' Profile

\begin{tabular}{cccc}
\hline Participants & $\begin{array}{c}\text { Degree } \\
\text { Level }\end{array}$ & Stage of Candidacy & Country \\
\hline P1 & PhD & $1^{\text {st }}$ year & Malaysia \\
P2 & Masters & $2^{\text {nd }}$ years & Malaysia \\
P3 & PhD & $2^{\text {nd }}$ year & China \\
P4 & Masters & $2^{\text {nd }}$ year & Malaysia \\
P5 & Masters & $\begin{array}{c}\text { Thesis submitted and } \\
\text { under examination }\end{array}$ & Nigeria \\
P6 & Masters & $\begin{array}{c}\text { Thesis submitted and } \\
\text { under examination }\end{array}$ & Malaysia \\
\hline
\end{tabular}

Open and exploratory interviews that lasted between 45-90 minutes were conducted with five full-time postgraduates, while the sixth student requested an e-mail interview. Before the interviews commenced, participants were sent an information sheet and consent form, which was signed and returned. A copy of the interview protocol was also included (see Appendix 1), and questions spanned three broad areas:

(i) Academic writing perceptions

(ii) Academic writing challenges

(iii) Support sought for academic writing 
These questions were developed based on the research question and existing literature on postgraduate education. The interviews were audio recorded and transcribed. Interview transcripts were later sent to participants via e-mail to be checked for accuracy. They were requested to make changes to the information where necessary.

Analysis of the transcripts followed a general inductive approach (Thomas, 2006) which has been recognised for its flexibility, and straightforward set of analysis procedures (Liu, 2016). This approach enables raw data to be condensed to summary format; research objectives to be linked to summary findings; and a theory or model about the underlying structure of experiences to be developed from the data (Thomas, 2006).

The process started with the preparation of raw data files that were formatted, page numbered and printed to ease referencing. Next, frequent, dominant, or significant themes were identified from the raw data. At times, certain segments of texts were assigned to more than one sub-theme, while at other times, there was a considerable amount of text that was not coded into any category because it did not relate to the research objectives. The initial analysis resulted in several codes that were narrowed down to three main themes. It is believed that having a few themes enables deep details to be obtained (Cresswell, 2007). Transcripts were read numerous times so that commonalities, differences and distinctive features across the data set, and relationships between the various elements in the analysis could be examined.

\section{RESULTS AND DISCUSSION}

\section{a) Academic Writing Support}

\section{(i) Academic English support}

The first area that students expressed a need for support was in academic English. Singh and Mayer (2014) explain that students and researchers in the Science field are usually well trained and motivated in designing, performing experiments and analysing data. However, many have not received any formal training in writing. Similarly, many of the participants of this study were unfamiliar 
with the conventions of scientific scholarly writing. Aside from that, writing in the English language was a significant challenge because all students were from non-English speaking backgrounds.

P4 expressed that he did not know how to write a well-structured paragraph, which he believed would be helpful when writing his literature review: "How to structure it (literature review) to become a good paragraph. To make it into a good subtopic which contains five or six paragraphs. Nobody really has really taught us." P4 related that the university had provided him the opportunity to be part of a semester long supplementary English class for undergraduate students so that he could learn basic grammar and writing skills. However, as a postgraduate student, he needed to have additional support in learning how to write the Literature Review and Discussion chapters in his thesis; which was not necessarily available in the undergraduate level class he joined.

Most students also needed support in proof-reading and editing. P3 suggested that the university set up a panel of experts that could be consulted when students encountered writing problems. Although P4 and P6 hoped that the university had proof-reading services, P6 related that he was unsure whether it was the responsibility of the university to provide this.

\section{(ii) Writing support}

Participants recognised that writing was not a solitary, autonomous activity and believed writing could be facilitated through peer support groups and workshops. P5 remarked that the university's postgraduate society could play a part in starting such peer groups, and in doing so connect postgraduates:

(The society can ask) Oh, we have students going for this conference. Is anyone free to volunteer to be the audience and to offer one or two comments that can help? Or to review a paper and to offer a different perspective?

Published accounts of peer support groups in Malaysia are rather limited. However, Stracke and Kumar (2014) describe a support group initiative in Universiti Putra Malaysia from 2006 to 2011, 
that not only focused on activities involving writing, but also social and career development activities, as well as practical day-to-day management of the research process. Working in teams is common in the Science field. When feedback is sought from team members, improved text quality will likely ensue because inconsistencies, inappropriate text structures, unclear messages, wordy text parts and errors can be easily detected (Singh \& Mayer, 2014). Therefore, sociality in writing is an essential part of the writing process, which consequently led P2 to share: "I think it will be nice to have more support - like when we write something, we give a few people to read. People who you know will give constructive feedback."

NESB peer writing groups can provide a supportive environment and continual assistance to students throughout the writing process. $\mathrm{Li}$ and Vandermensbrugghe (2011) found that students gained increased language use awareness and reader awareness because they became readers for each other. This makes peer learning 'horizontal' because students learn with and from each other. Aitchison and Lee (2006) claim that though there are notions that writing is a solitary pursuit, it is in fact a process that involves a network of social, institutional and peer relations.

Additionally, most of the participants felt that academic writing challenges could be mitigated through workshops and seminars. P2 related why participating in workshops would be satisfying: “... all the energy and focus is on that particular subject, then the outcome of that will be more satisfying.... And writing by yourself is hard. There is no one to gauge your progress."

While P2 wanted more writing workshops, P4 felt that sometimes, generic workshops were not beneficial because these were one-off events: “... It is not really helping us in the writing. It creates some kind of awareness, but not so much on the (writing) techniques itself." Instead of the one-off generic workshops, he believed that it would be useful if the university provided comprehensive writing classes at the early stages of candidacy so that students could gain the needed writing skills which would set them on a good path towards writing. Based on the needs expressed, it appears that a more systematic, and programmatic approach towards the teaching of writing was sought. 


\section{b) Supervisory Support}

Students recognised that supervisory support greatly influenced writing progress. Lessing and Schulze (2002) observe that most students are aware of their educational rights and are likely to demand competent and accessible supervisors. They add that this makes it important for clarity on the roles and responsibilities of both students and supervisors. P1 hoped to receive clearer expectations from her supervisor and suggested a supervisor-student agreement at the start of candidature. P2 felt that her supervisor could have helped set specific deadlines for her:

I would have worked better with proper deadlines. And if I set my own deadlines, I won't follow them because it is just a commitment to myself; it is not like I am accountable or whatever... The whole period I was really stressed out because I didn't really know what I was expected to write.

While P2 sought a supervisor who could help her develop a sense of accountability, P4 expressed his need for clearer writing instruction:

I don't know if my literature review is too broad or too narrow so... or what kind of sub-topics that I should include. Whether what I include is specific to this particular type of work or maybe I have put something that is not related.

Starke-Meyerring (2011) found that doctoral students experienced a sense of being left in the dark, and were often made to learn through trial and error. She argues that students can feel this way when there is a lack of exchange and dialogue about writing, which results in it being 'hidden from plain sight' and treated as normalised and 'common sense'. While supervisors provide insight into disciplinary knowledge and advice on research design, they may not always provide engagement with issues of reading and writing (Fergie et al., 2011). Moreover, while it may be common practice for supervisors to correct syntactic and spelling errors on draft chapters, many may not provide explanations or instruction on how to correct these errors, which consequently demoralize students because they are led 
to feel that their writing is 'faulty' (Larcombe et al., 2007). There was one student who believed that supervisors should also provide language support: "The supervisor should be able to pinpoint language problems. That means the supervisor needs to be strong in the language as well before she can assist the students." (P1)

As academic writing is a crucial skill in postgraduate research, writing support from supervisors may be required to ensure students' progress and success. However, the role of the supervisor in terms of writing development is contentious as some feel that they are not responsible for teaching writing (Larcombe et al., 2007; StarkeMeyerring, 2011). Another concern is that many supervisors may also not know how to teach writing and be unfamiliar with writing pedagogy. In certain situations, supervisors may rely on their own experiences of being supervised as ideals to emulate, and this may not always prove to be helpful (Badenhorst et al., 2015). In Malaysia, some supervisors are from non-English speaking backgrounds, and have an added linguistic burden and demand placed on them as English language writing teachers. Khozaei et al. (2015) highlight that the academic weaknesses and incompetence of supervisors can prolong the research journey; however, none of the participants in this study reported that supervisors were obstacles to their writing progress.

\section{c) Information and Communication Technology Support}

(ICT)

The third finding that emerged was for greater ICT support. Students reported utilising technology to assist in research writing and mentioned the integration of various software. Four students felt that their writing needs could be supported if the university obtained licences for software that they frequently used. P4 utilised a software called Ginger and he liked using it because it could be integrated into the web browser and Microsoft Word documents. However, P4 reported that access was limited: “... if you highlight certain parts of your write-up and if you click that icon, it can check the parts that you highlight. But it is limited to certain number of sentences per week." Because P4 was utilising a free version, he was limited to a certain number of sentences per week, and this impeded writing. Therefore, he felt that his writing process would have been smoother if the university had obtained a licence for this software so that students could have wider access to this tool. 
Similarly, P5 also utilised a software to aid in research writing and found it beneficial because in addition to correcting grammar and punctuation, it also was a learning tool. P5 shared:

Another thing that helped me was also this software called Grammarly. I noticed that I was very poor in punctuation. ... So maybe if the university could help us purchase the license. It gives you a lot of information, tells you why this word isn't correct... .

Singh and Mayer (2014) provide a long list of software tools for various stages of the writing process and argue that these technologies enable the writing process to be more creative, effective and manageable instead of long and cumbersome. To support students, universities can provide access to these writing tools and also conduct workshops on how to incorporate them in writing. Students can be encouraged to utilise these technologies to improve writing speed and text quality, and supervisors can also promote its use in writing. ICT can also be incorporated into supervision pedagogy, as observed by some supervisors in Australian institutions who use tools such as Dropbox, Skype, Twitter and e-mail to foster more connected, collaborative and intense relationships (Maor \& Currie, 2017).

While most students wanted more ICT related support during the write-up phase, there was one student who needed support close to the submission stage. Before students in the participating institution hand in their thesis for examination, they are required to submit their thesis through various text-matching software like Turnitin and SafeAssign. P5 lamented: “...we were never taught or briefed as research students about the Turnitin software - how to interpret the data. All we were taught is when you are done, submit it and print out your report." He felt that it would be helpful for both supervisors and students to be briefed on issues relating to plagiarism and the use of text-matching software. A common perception that exists is that students who enter postgraduate study have the needed computer skills for study purposes, which then makes it unnecessary to provide computer training to students at this level (Dange, 2010). In this case however, it was evident that while knowing how to use ICT is important, knowing how to interpret and understand data obtained from usage is also equally essential. 


\section{CONCLUSION}

The findings showed that students required support in three main areas: a) academic writing, b) supervision and c) ICT. Students felt that they needed support in academic English and believed that initiatives such as peer support groups and workshops could enhance writing. Students also recognised the importance of support and guidance from supervisors and felt that writing needed to be addressed comprehensively and explicitly. Finally, some students sought premium access to software and writing tools because they found that these improved their writing. Students also needed guidance on how to interpret data obtained from certain textmatching software, especially towards the submission stage.

Although this study focused on a small group of local and international students in the Malaysian context, the findings may be useful to those in other contexts. With greater student diversity through the internationalisation of higher education, many NESB students enrol in institutions worldwide. Furthermore, academic writing support is gaining recognition as an area that all students require, regardless of linguistic or educational background (Wilmot, 2018). Therefore, in the case of students from branch campuses of overseas universities, future studies could include experiences of students from main campuses as well. It might be useful to do a comparative study on these experiences, and to also explore supervisor experiences. Based on the findings of this study and literature on postgraduate education, a 3P approach is recommended to support postgraduate research writing. To meet the needs of students, it is suggested that postgraduate support is pedagogically $(\mathrm{P} 1)$ driven, peer $(\mathrm{P} 2)$ oriented and programmatically (P3) implemented.

First, supervisors need to be explicitly instructed in pedagogies of supervision. They cannot merely rely on being subject experts who model their own experiences of being supervised. Supervisor training may include how to deliver feedback, how to manage students' expectations and how to incorporate ICT. Thesis and research writing also needs to be pedagogy driven, with students being taught how to write for academic purposes. As evidenced in previous research, NESB students struggle linguistically and this can impede research writing. It cannot be taken for granted that students will pick up writing on their own; instead academic English and writing conventions need to be taught explicitly. 
Second, it has been documented in numerous studies that the postgraduate journey is often a lonely one. Hence, peer support can aid in alleviating the feeling of isolation. Peer support does not only have to be in the form of writing groups but can also be in the form of cohort models of supervision and general support groups where members learn together and provide emotional support for one another. This could help foster a sense of belonging to a community which strives towards similar goals and journeys through somewhat similar experiences.

Finally, academic support would be more effective if it were programmatically and systematically delivered. There needs to be some coherence in workshops provided for students, and they should meet the needs to students at various stages of candidature. Programmes that students might find useful can range from supervisor mentorship programmes to EAP preparation programmes by language advisors. If support were available in a more sustained and programmatic way, students will be able to see structure in the support received and the research journey would be less uncertain.

\section{ACKNOWLEDGEMENT}

This research received no specific grant from any funding agency in the public, commercial, or not-for profit sectors.

\section{REFERENCES}

Abdulkareen, M. N. (2013). An investigation study of academic writing problems faced by Arab postgraduate students at Universiti Teknologi Malaysia (UTM). Theory and Practice in Language Studies, 3(9), 1552-1557. https://doi.org/10.4304/ tpls.3.9.1552-1557

Aitchison, C., \& Lee, A. (2006). Research writing: Problems and pedagogies. Teaching in Higher Education, 11(3), 265-278. https://doi.org/10.1080/13562510600680574

Atkins, S., Varshney, D., Meragia, E., Zwarenstein, M., Diwan, V., for the ARCADE Consortium. (2016). 'Research clinics': Online journal clubs between south and north for student mentoring. Global Health Action, 9(1), 30434.

Badenhorst, C., Moloney, C., \& Rosales, J. (2015). Beyond deficit: Graduate student research-writing pedagogies. Teaching in Higher Education, 20(1), 1-11. https://doi.org/10.1080/1356 2517.2014.945160 
Buissink-Smith, N., Hart, S., \& van der Meer, J. (2013). `There are other people out there!' Successful postgraduate peer groups and research communities at a New Zealand university. Higher Education Research \& Development, 32(7), 695-705. https://doi.org/10.1080/07294360.2013.777034

Burnett, P. C. (1999). The supervision of doctoral dissertations using a collaborative cohort model. Counselor Education and Supervision, 39(1), 46-52. https://doi.org/10.1002/j.15566978.1999.tb01789.x

Carter, S. (2011). Doctorate as genre: Supporting thesis writing across campus. Higher Education Research \& Development, 30(6), 725-736. https://doi.org/10.1080/07294360.2011.5543 88

Cresswell, J. W. (2007). Qualitative inquiry and research design: Choosing among five approaches (2nd ed.). Thousand Oaks, USA: SAGE Publications.

Curtin, N., Malley, J., \& Stewart, A. J. (2016). Mentoring the next generation of faculty: Supporting academic career aspirations among doctoral students. Research in Higher Education, 57, 714-738. https://doi.org/10.1007/s11162-015-9403-x

Czarniawska, B. (2004). Narratives in social science research. London, UK: SAGE Publications.

Dange, J. K. (2010). Postgraduate students' computing confidence, computer and Internet usage at Kuvempu University--an Indian study. International Joural of Instruction, 3(2), 3962.

Davis, G., Wright, H., \& Holley, D. (2016). Write away from it all! The value of running a writing retreat for doctoral students. Practitioner Research in Higher Education, 10(2), 54-66.

de Lange, N., Pillay, G., \& Chikoko, V. (2011). Doctoral learning: A case for a cohort model of supervision and support. South African Journal of Education, 31(1), 15-30. https://doi. org/10.15700/saje.v31n1a413

Denzin, N. K., \& Lincoln, Y. S. (2003). Introduction : The discipline and practice of qualitative research. In N. K. Denzin \& Y. S. Lincoln (Eds.), The landscape of qualitative research: Theories and issues. (pp. 1-46). Thousand Oaks, USA: SAGE Publications.

Fergie, G., Beeke, S., Mckenna, C., \& Creme, P. (2011). “ It' s a lonely walk ": Supporting postgraduate researchers through writing. International Journal of Teaching and Learning in Higher Education, 23(2), 236-245. 
Franken, M. (2012). Re-situation challenges for international students 'becoming' researchers. Higher Education, 64(6), 845-859. https://doi.org/10.1007/s10734-012-9532-5

Huwari, I. F., \& Abd.Aziz, N. H. (2011). Writing apprehension in English among Jordanian postgraduate students at Universiti Utara Malaysia (UUM). Academic Research International, 1(2), 190-198. Retrieved from www.journals.savap.org.pk

Ibrahim, N., \& Nambiar, R. M. K. (2011). Writing in foreign lands: The case of postgraduate international students and the introductory sections of a project paper. Procedia Social and Behavioral Sciences, 18, 626-632. https://doi.org/10.1016/j. sbspro.2011.03.356

Son, J-B., \& Park, S-S. (2014). Academic experiences of international $\mathrm{PhD}$ students in Australian higher education: From an EAP program to a $\mathrm{PhD}$ program. International Journal of Pedagogies and Learning, 9(1), 26-37. https://doi. org/http://dx.doi.org/10.1080/18334105.2014.11082017

Jeyaraj, J.J. (2018). It's a jungle out there : Challenges in postgraduate research writing. GEMA Online Journal of Language Studies, 18(1), 22-37. https://doi.org/http://doi.org/10.17576/gema2018-1801-02 22

Jomaa, N. J., \& Bidin, S. J. (2017). Perspectives of EFL doctoral students on challenges of citations in academic writing. Malaysian Journal of Learning and Instruction, 14(2), 177209.

Jones, G., Farrell, H., \& Goldsmith, R. (2009). Paradigm shift from student to researcher : An academic preparation program for international students. Journal of Academic Language \& Learning, 3(2), 61-69.

Khozaei, F., Naidu, S., Khozaei, Z., \& Salleh, N. A. (2015). An exploratory study of factors that affect the research progress of international $\mathrm{PhD}$ students from the Middle East. Education \& Training, 57(4), 448-460. https://doi.org/10.1108/ET-092013-0115

Larcombe, W., McCosker, A., \& O’Loughlin, K. (2007). Supporting education $\mathrm{PhD}$ and $\mathrm{DEd}$ students to become confident academic writers: An evaluation of thesis writers ' circles. Journal of University Teaching and Learning Practice, 4(1), 54-63. Retrieved from http://ro.uow.edu.au/jutlp/vol4/iss1/6/

Lee, S. (2017). Peer support for international doctoral students in managing supervision relationships. Journal of International 
Students, 7(4), 1096-1103. https://doi.org/10.5281/ zenodo.1035971

Lessing, A., \& Schulze, S. (2002). Postgraduate supervision and academic support: Students' perceptions. South African Journal of Higher Education, 16(2), 139-149. https://doi. org/10.4314/sajhe.v16i2.25253

Li, L. Y., \& Vandermensbrugghe, J. (2011). Supporting the thesis writing process of international research students through an ongoing writing group. Innovations in Education and Teaching International, 48(2), 195-205. https://doi.org/10.1 080/14703297.2011.564014

Lim, P. C., Sidhu, G. K., Fook, C. Y., Fong, L. L., \& Jamian, L. S. (2016). Assessing writing skills of postgraduate students: Perspectives of supervisors and supervisees. In S. F. Tang \& L. Logonnathan (Eds.), Assessment for learning within and beyond the classroom: Taylor's 8th teaching and learning conference 2015 proceedings (pp.31-41). Singapore: Springer Singapore. https://doi.org/10.1007/978-981-10-0908-2

Lincoln, Y. S., \& Guba, E. G. (2003). Paradigmatic controversies, contradictions, and emerging confluences. In N. K. Denzin \& Y. S. Lincoln (Eds.), The landscape of qualitative research : theories and issues (2nd ed., pp. 253-291). Thousand Oaks: SAGE Publications.

Liu, L. (2016). Using generic inductive approach in qualitative educational research: A case study analysis. Journal of Education and Learning, 5(2), 129-135. https://doi. org/10.5539/jel.v5n2p129

Maor, D., \& Currie, J. K. (2017). The use of technology in postgraduate supervision pedagogy in two Australian universities. International Journal of Educational Technology in Higher Education, 14(1), 1-15. https://doi.org/10.1186/ s41239-017-0046-1

McCulloch, A., Kumar, V., van Schalkwyk, S., \& Wisker, G. (2016). Excellence in doctoral supervision: An examination of authoritative sources across four countries in search of performance higher than competence. Quality in Higher Education, 22(1), 64-77. https://doi.org/https://doi.org/10.10 80/13538322.2016.1144904

Ministry of Education Malaysia. (2015). Malaysia education blueprint 2015-2025 (Higher Education). Putrajaya.

Mohd Isa, P., \& Ahmad, Y. (2018). Scrutinizing the issues and challenges faced by postgraduate students: An effort to design 
specific programs to inculcate research culture. Journal of Administrative Science, 15(1), 1-17.

Murray, R., \& Newton, M. (2009). Writing retreat as structured intervention: margin or mainstream? Higher Education Research and Development, 28(5), 541-553. https://doi. org/10.1080/07294360903154126

Nulty, D., Kiley, M., \& Meyers, N. (2009). Promoting and recognising excellence in the supervision of research students: An evidence-based framework. Assessment and Evaluation in Higher Education, 34(6), 693-707. https://doi. org/10.1080/02602930802474193

Ohnishi, S., \& Ford, J. H. (2015). Student seminar program for improving academic presentation skills for $\mathrm{PhD}$ students in science: The effect of language background on outcome. International Journal for Researcher Development, 6(1), 5776. https://doi.org/10.1108/IJRD-09-2014-0027

Paglis, L. L., Green, S. G., \& Bauer, T. N. (2006). Does adviser mentoring add value? A longitudinal study of mentoring and doctoral student outcomes. Research in Higher Education, 47(4), 451-476. https://doi.org/10.1007/s11162-005-9003-2

Phakiti, A., \& Li, L. (2011). General academic difficulties and reading and writing difficulties among Asian ESL postgraduate students in TESOL at an Australian University. RELC Journal, 42(3), 227-264. https://doi.org/10.1177/0033688211421417

Sidhu, G. K., Kaur, S., Fook, C. Y., \& Yunus, F. W. (2013). Postgraduate supervision: Exploring Malaysian students' experiences. Procedia - Social and Behavioral Sciences, 90, 133-141. https://doi.org/doi: 10.1016/j.sbspro.2013.07.074

Sidhu, G. K., Kaur, S., Fook, C. Y., \& Yunus, F. W. (2014). Postgraduate supervision: Comparing student perspectives from Malaysia and the United Kingdom. Procedia - Social and Behavioral Sciences, 123, 151-159. https://doi.org/10.1016/j. sbspro.2014.01.1409

Sidhu, G. K., Kaur, S., Lim, P. C., \& Fook, C. Y. (2016). Assessing the critical reading skills of postgraduate Students: Perspectives of supervisors and supervisees. In S. F. Tang \& L. Logonnathan (Eds.), Assessment for learning within and beyond the classroom: Taylor's 8th teaching and learning conference 2015 proceedings (pp.43-52). Singapore: Springer Singapore. https://doi.org/10.1007/978-981-10-0908-2

Singh, V., \& Mayer, P. (2014). Scientific writing: Strategies and tools for students and advisors. Biochemistry and Molecular 
Biology Education, 42(5), 405-413. https://doi.org/10.1002/ bmb.20815

Starke-Meyerring, D. (2011). The paradox of writing in doctoral education: Studentexperiences. InL.McAlpine \& C.Amundsen (Eds.), Doctoral education: Research-based strategies for doctoral students, supervisors and administrators (pp. 7595). Springer Netherlands. https://doi.org/10.1007/978-94007-0507-4

Storch, N., \& Tapper, J. (2009). The impact of an EAP course on postgraduate writing. Journal of English for Academic Purposes, 8(3), 207-223. https://doi.org/10.1016/j. jeap.2009.03.001

Stracke, E., \& Kumar, V. (2014). Realising graduate attributes in the research degree: The role of peer support groups. Teaching in Higher Education, 19(6), 1-14. https://doi.org/10.1080/1356 2517.2014.901955

Thomas, D. R. (2006). A general inductive approach for analyzing qualitative evaluation data. American Journal of Evaluation, 27(2), 237-246. https://doi.org/10.1177/1098214005283748

Wilkins, S., \& Huisman, J. (2012). The international branch campus as transnational strategy in higher education. Higher Education, 64, 627-645. https://doi.org/10.1007/s10734-0129516-5

Wilmot, K. (2018). Designing writing groups to support postgraduate students' academic writing: A case study from a South African university. Innovations in Education and Teaching International, 55(3), 257-265. https://doi.org/10.1080/14703 297.2016.1238775

Wisker, G., Robinson, G., Trafford, V., Lilly, J., \& Warnes, M. (2004). Achieving a doctorate: Metalearning and research development programmes supporting success for international distance students. Innovations in Education and Teaching International, 41(4), 473-489. https://doi. org/10.1080/1470329042000277048

Woodward-Kron, R. (2007). Negotiating meanings and scaffolding learning: Writing support for non-English speaking background postgraduate students. Higher Education Research \& Development, 26(3), 253-268. https://doi. org/10.1080/07294360701494286

Zaccagnini, M., \& Verenikina, I. (2013). Peer assisted study sessions for postgraduate international students in Australia. Journal of Peer Learning, 6, 86-102. Retrieved from http://ro.uow. edu.au/ajpl/vol6/iss $1 / 8$ 
Zainal Abiddin, N., \& Ismail, A. (2011). Attrition and completion issues in postgraduate studies for student development. International Review of Social Sciences and Humanities, 1(1), 15-29. https://doi.org/10.1080/18146620902857574

Zakariah, Z., Hashim, R. A., \& Musa, N. (2018). Motivation of postgraduate learners in pursuing their doctoral degree through collaborative learning. In 3rd UUM International Qualitative Research Conference (QRC) 2018 (pp. 148-153). 